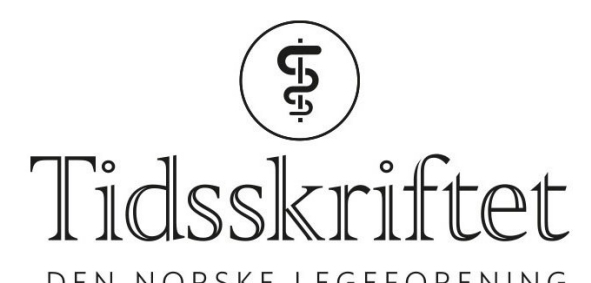

DEN NORSKE LEGEFORENING

\title{
Rusmiddelforgiftninger på legevakt
}

DOKTORAVHANDLINGER

ODD MARTIN VALLERSNES

E-post: o.m.vallersnes@medisin.uio.no

Enkle undersøkelser av pasienter med rusmiddelforgiftning på legevakt kan fange opp farlige forgiftninger.

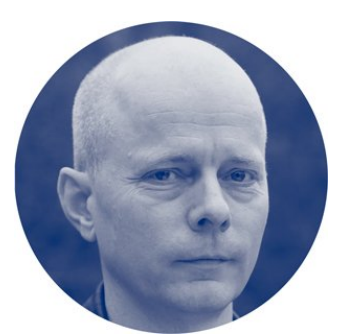

Odd Martin Vallersnes. Foto:

Anbjørg Kolaas

I Oslo behandles de fleste pasienter med rusmiddelforgiftning ved Legevakten i Oslo, med enkle verktøy for diagnostikk og behandling.

I løpet av ett år registrerte vi alle rusmiddelforgiftninger ved legevakten, kartla oppfølgingen etterpå, registrerte dødsfall, kontakter med spesialisthelsetjeneste og fastlege samt rekontakter ved legevakten. Data ble hentet fra vårt eget journalsystem og nasjonale registre.

Av totalt 2343 rusmiddelforgiftninger ble pasienten innlagt i sykehus i $17 \%$ av tilfellene. Ingen døde ved Legevakten i Oslo. To døde den første uken etter å ha blitt sendt hjem, begge av en ny opioidforgiftning. Av de hjemsendte kom o,7\% tilbake til legevakt eller sykehus med behov for ytterligere behandling av den samme forgiftningen eller på grunn av andre uoppdagede tilstander. Imidlertid kom 9\% tilbake med en ny forgiftning i løpet av en uke. Pasienten ble henvist til spesialisthelsetjenesten i 10\% av tilfellene, $85 \%$ av disse møtte opp. De ble rådet til å ta kontakt med fastlegen i $4 \%$ av tilfellene, av disse fulgte halvparten rådet. Legevakten i Oslo virker å ha trygge vurderingsrutiner ved rusmiddelforgiftninger, rutiner som også kan være nyttige andre steder. Få pasienter ble henvist videre eller rådet til å kontakte fastlegen etter forgiftning, men en stor andel av dem som ble henvist, møtte opp.

\section{Disputas}

Odd Martin Vallersnes disputerte for ph.d.-graden ved Universitetet i Oslo 20. januar 2017. Tittelen på avhandlingen er Acute poisoning by substances of abuse in Oslo: epidemiology, 
outpatient treatment, and follow-up.

Publisert: 26. juni 2017. Tidsskr Nor Legeforen. DOI:10.4045/tidsskr.17.0246

(C) Tidsskrift for Den norske legeforening 2020. Lastet ned fra tidsskriftet.no 